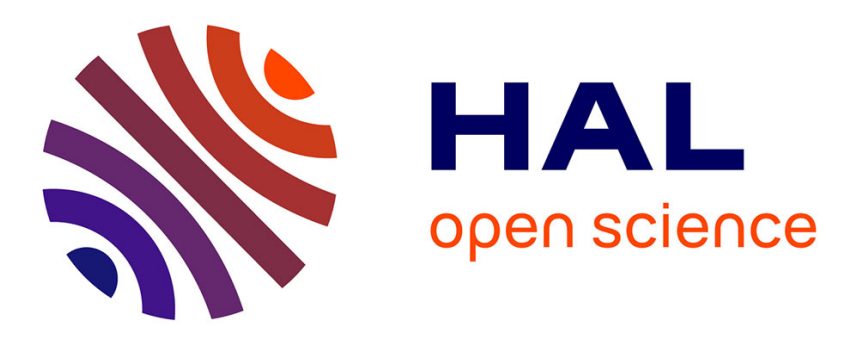

\title{
Effects of nitrogen underfeeding and energy source on nitrogen ruminal metabolism, digestion, and nitrogen partitioning in dairy cows
}

Audrey Fanchone, Pierre Noziere, Josiane Portelli, Beatrice Duriot, Vincent Largeau, Michel M. Doreau

\section{To cite this version:}

Audrey Fanchone, Pierre Noziere, Josiane Portelli, Beatrice Duriot, Vincent Largeau, et al.. Effects of nitrogen underfeeding and energy source on nitrogen ruminal metabolism, digestion, and nitrogen partitioning in dairy cows. Journal of Animal Science, 2013, 91 (2), pp.895 - 906. 10.2527/jas20125296. hal-02642841

\section{HAL Id: hal-02642841 \\ https://hal.inrae.fr/hal-02642841}

Submitted on 28 May 2020

HAL is a multi-disciplinary open access archive for the deposit and dissemination of scientific research documents, whether they are published or not. The documents may come from teaching and research institutions in France or abroad, or from public or private research centers.
L'archive ouverte pluridisciplinaire HAL, est destinée au dépôt et à la diffusion de documents scientifiques de niveau recherche, publiés ou non, émanant des établissements d'enseignement et de recherche français ou étrangers, des laboratoires publics ou privés. 


\title{
Effects of nitrogen underfeeding and energy source on nitrogen ruminal metabolism, digestion, and nitrogen partitioning in dairy cows ${ }^{1}$
}

\author{
A. Fanchone, ${ }^{2}$ P. Nozière, ${ }^{3}$ J. Portelli, B. Duriot, V. Largeau, and M. Doreau \\ INRA/VetAgro Sup, UMR1213 Herbivore Research Unit, 63122 Saint-Genès Champanelle, France
}

\begin{abstract}
This work aimed to investigate the effects of 2 levels of $\mathrm{N}$ (low or high) and 2 energy sources (starch or fiber) on $\mathrm{N}$ partitioning, $\mathrm{N}$ ruminal metabolism, and digestion in dairy cows. Four Holstein cows were used in a $4 \times 4$ Latin square design. The 4 cows (on average, $662 \pm 62 \mathrm{~kg}$ and at $71 \pm 10 \mathrm{~d}$ in milk at the beginning of the experiment) were fitted with rumen, proximal duodenum, and terminal ileum cannula. The cows received 4 diets having the same forage proportion on a DM basis. The high level of $\mathrm{N}$ supply met $110 \%$ of the protein requirements of cows with an adequate supply in rumen-degradable $\mathrm{N}$. The low level covered $80 \%$ of these requirements with a shortage in rumen-degradable N. Energy sources differed by their nature (i.e., starch from barley, corn, and wheat or fiber from soybean hulls and dehydrated beet pulp). Duodenal digesta flow was determined using $\mathrm{YbCl}_{3}$ as a marker. Microbial duodenal $\mathrm{N}$ flow was determined using purine and pyrimidine bases as markers from liquid-associated bacteria and mixed bacteria samples. Microbial $\mathrm{N}$ flow and efficiency of microbial protein synthesis, calculated using mixed bacteria as a reference microbial sample, were not significantly modified by the $\mathrm{N}$ level $(P=0.19$ and 0.29 ,
\end{abstract}

respectively) and the energy source of the diet $(P=0.11$ and 0.08 , respectively). Total tract apparent digestibility of OM and total tact digestibility of NDF were lower at the low $\mathrm{N}$ level ( $P=0.006$ and 0.007 , respectively). Total tract apparent digestibility of OM tended to be greater $(P=0.08)$ with high-starch diets than with high-fiber diets. Total tact digestibility of NDF was greater $(P<$ $0.001)$ with high-fiber diets than with high-starch diets. Duodenal $\mathrm{N}$ flow was less $(P=0.001)$ at the low $\mathrm{N}$ level than high $\mathrm{N}$ level and tended to be greater $(P=0.06)$ with high-starch diets than with high-fiber diets. Daily output of $\mathrm{N}$ in urine was less $(P<0.001)$ at the low $\mathrm{N}$ level than at the high $\mathrm{N}$ level. Daily output of $\mathrm{N}$ in feces did not differ between low and high $\mathrm{N}$ levels $(P=0.24)$ and between high-starch and high-fiber diets $(P=0.17)$. Milk yield and protein yield were less $(P=0.002$ and $P=$ 0.013 , respectively) at the low $\mathrm{N}$ level than at the high $\mathrm{N}$ level. Milk fat yield tended to be less $(P=0.09)$ at the low $\mathrm{N}$ level than at the high $\mathrm{N}$ level and with high-starch than with high-fiber diets $(P=0.06)$. In conclusion, a large reduction in dietary $\mathrm{N}$ led to reduced $\mathrm{N}$ excretion in urine and decreased milk production but did not affect $\mathrm{N}$ excretion in feces or microbial protein synthesis.

Key words: carbohydrate, nitrogen partition, protein, rumen metabolism

J. Anim. Sci. 2013.91:895-906 doi:10.2527/jas2012-5296

\section{INTRODUCTION}

\footnotetext{
${ }^{1}$ The authors thank the Commission of the European Communities, project FP7-KBBE-2007-1 "Rednex," for financial support; D. Durand, D. Rémond, and P. Gaydier for animal surgery; F. Anglard, D. Chassaignes, S. Rudel, and the staff of "Les Cèdres" for animal care and help in sampling; E. Aurousseau, P. Amblard, L. Genestoux, and the staff of "DIMA" for their great technical participation; and N. Hafnaoui for AA analysis.

${ }^{2}$ Present address: INRA, UR143 Tropical Animal Science Unit, 97170 Petit-Bourg, Guadeloupe (FWI), France.

${ }^{3}$ Corresponding author: pierre.noziere@clermont.inra.fr

Received March 16, 2012.

Accepted April 15, 2012.
}

There is increasing concern over the role of livestock farming in environmental issues (Steinfeld et al., 2006). In dairy cows, $\mathrm{N}$ losses in feces and urine are a major cause of $\mathrm{N}$ pollution (Tamminga, 1992). Decreasing dietary $\mathrm{N}$ intake by dairy cows is one strategy for reducing $\mathrm{N}$ output in urine (Huhtanen and Hristov, 2009; Agle et al., 2010) or feces or both (Kebreab et al., 2001; Cyriac et al., 2008) but is only viable if it does not significantly impair animal performance. One 
way forward would be to improve the efficiency of dietary $\mathrm{N}$ utilization (Calsamiglia et al., 2010). Nitrogen metabolism in the rumen, which has been identified as the major factor driving the efficiency of $\mathrm{N}$ utilization by ruminants (Tamminga, 1992), is divided into 2 main events: dietary protein degradation and microbial protein synthesis (Bach et al., 2005). It is well known that $\mathrm{N}$ from dietary protein degradation and ammonia recycling through the gut are the 2 sources of $\mathrm{N}$ for microbial synthesis [Institut National de la Recherche Agronomique (INRA), 2007]. Thus, a severe shortage in rumen-degradable $\mathrm{N}$ may affect negatively both microbial growth and efficiency (Reynal and Broderick, 2005).

Otherwise, the nature of the dietary energy supply may affect rumen degradability and the rate of ruminal fermentation (Sauvant and Van Milgen, 1995; Hristov and Jouany, 2005) and interact with protein digestion and metabolism (Firkins, 1996). In addition, microbial N synthesis may depend on the nature of the bacterial ecosystem, which differs according to the energy source (Belanche et al., 2012).

To our knowledge, information on the effects of a very low dietary CP content in interaction with the energy source on $\mathrm{N}$ ruminal metabolism, digestion, and $\mathrm{N}$ partitioning in dairy cows is very scarce. Our hypothesis was that microbial protein synthesis would compensate for a decrease in dietary $\mathrm{N}$ supply, especially when starch was used as the energy source in the diet.

\section{MATERIALS AND METHODS}

Care and use of animals were performed in accordance with national legislation issued by the French ministry in charge of agriculture (Ministère de l'Alimentation, de l'Agriculture et de la Pêche, 2009) and international recommendations (Canadian Council on Animal Care, 1993) on the care and use of laboratory animals.

\section{Cows, Experimental Design, and Diets}

This study used 4 Holstein cows weighing on average $662( \pm 62) \mathrm{kg}$ at $71( \pm 10) \mathrm{d}$ of lactation at the beginning of the experiment ( 1 lof the first period). The cows were fitted with permanent ruminal cannulas made of polyamide-polyvinyl chloride (Synthesia, Nogent-surMarne, France) and T-shaped cannulas made of plastisol (Synthesia) with a gutter-type base placed at the proximal duodenum before bile duct entrance and at the terminal ileum. Surgery was performed under general anesthesia (Isoflurane, ICIU Pharma-vétérinaire, Paris, France). The cows were penned in individual stalls. Four dietary treatments were applied to the cows during 4 successive periods in a $4 \times 4$ Latin square design. Each experimental period lasted $28 \mathrm{~d}$ and consisted of $22 \mathrm{~d}$ of adaptation to the diet and $6 \mathrm{~d}$ of measurements. Treatments were 2 levels of $\mathrm{N}$ and 2 energy sources. The high level of $\mathrm{N}$ met $110 \%$ of protein requirements of cows expressed in the French protein digestible in the intestine system (INRA, 2007), whereas the low level covered $80 \%$ of these requirements, with a shortage in rumen-degradable $\mathrm{N}$. According to calculations based on NRC (2001), the high level of N covered $106 \%, 120 \%$, and $97 \%$ of MP, RDP, and RUP cow requirements, respectively, whereas the low levels of $\mathrm{N}$ covered $95 \%, 93 \%$, and $75 \%$ of MP, RDP, and RUP cow requirements, respectively. The difference between the 2 energy sources was based on the nature of concentrate (i.e., rich in starch or rich in fiber). The ingredients and chemical composition of the experimental diets are given in Table 1. The 4 diets had the same proportion of forage on a DM basis. At the high $\mathrm{N}$ level, the $\mathrm{N}$ supply was mainly based on soybean meal and urea. In high-starch diets, the cereal-based concentrate was made with $39 \%$ barley, $46 \%$ wheat, and $15 \%$ corn mixture. In high-fiber diets, the concentrate was made with a mixture of soybean hulls and dehydrated beet pulp. To avoid any effect of intake level on digestion, animals were fed restricted amounts based on $95 \%$ of voluntary intake. Voluntary intake was measured at the beginning of the experiment and adjusted to cow NE theoretical requirements (INRA, 2007) at the beginning of each experimental period. Average feed intake (mean of the 4 cows for the same diet) was the same among diets. The diet was distributed as total mixed ration twice daily at $0900(60 \%$ of the diet) and $1700 \mathrm{~h}(40 \%$ of the diet). These proportions (60:40) were retained to ensure that cows were not limited during the day and are based on previous observations of cow feeding behavior (Doreau and Rémond, 1982). Water was provided ad libitum. For each treatment, $200 \mathrm{~g}$ of mineralvitamin supplement was provided daily, added to the total mixed ration.

\section{Measurements, Sampling, and Analyses}

Feed Intake. Each diet ingredient was weighed individually before distribution as a total mixed ration. Intake was recorded by weighing amount of feed offered and refused daily for individual cows on d 22 to 28 . To calculate feed intake, the DM content of each diet ingredient was determined $\left(24 \mathrm{~h}\right.$ in a $103^{\circ} \mathrm{C}$ forced-air dry oven) on d 22 and 25. A 100-g sample of each ingredient of the diet was collected daily from d 24 to 28 for analysis of chemical composition. When refusals exceeded 1 $\mathrm{kg}$, they were analyzed (DM and chemical composition) to correct diet nutrient intakes. The DM content of refusals (when exceeding $1 \mathrm{~kg}$ ) was determined $(24 \mathrm{~h}$ in a $103^{\circ} \mathrm{C}$ forced-air dry oven), and a 100 -g sample was collected for analysis of chemical composition. Samples of corn silage and refusals (when exceeding $1 \mathrm{~kg}$ ) were stored at $-20^{\circ} \mathrm{C}$, whereas samples of other ingredients 
Table 1. Ingredient, chemical composition, and nutritive value of the diets fed to dairy cows receiving high-starch or high-fiber concentrate at a low or high $\mathrm{N}$ level

\begin{tabular}{|c|c|c|c|c|}
\hline \multirow[b]{2}{*}{ Item } & \multicolumn{2}{|c|}{ Low $\mathrm{N}$} & \multicolumn{2}{|c|}{ High N } \\
\hline & Starch & Fiber & Starch & Fiber \\
\hline \multicolumn{5}{|l|}{ Ingredients, ${ }^{1} \% \mathrm{DM}$} \\
\hline Corn silage & 40.5 & 40.5 & 40.5 & 40.5 \\
\hline Hay & 10.0 & 10.0 & 10.0 & 10.0 \\
\hline Dehydrated alfalfa & 9.0 & 9.0 & 9.0 & 9.0 \\
\hline Molassed chopped wheat straw & 6.3 & 0 & 5.2 & 0 \\
\hline Cereal-based concentrate $^{2}$ & 30.6 & 0 & 24.3 & 0 \\
\hline Soybean hulls & 0 & 31.0 & 0 & 22.4 \\
\hline Dehydrated beet pulp & 0 & 9.0 & 0 & 9.0 \\
\hline Soybean meal & 3.6 & 0 & 10.8 & 8.6 \\
\hline Urea & 0 & 0.5 & 0.2 & 0.5 \\
\hline \multicolumn{5}{|l|}{ Chemical composition, \% DM } \\
\hline $\mathrm{OM}$ & 94.3 & 93.3 & 93.8 & 93.0 \\
\hline NDF & 36.2 & 50.7 & 36.1 & 47.1 \\
\hline $\mathrm{ADF}$ & 18.8 & 30.7 & 18.4 & 27.4 \\
\hline $\mathrm{CP}$ & 11.0 & 11.1 & 14.2 & 14.4 \\
\hline Starch & 32.4 & 15.1 & 29.0 & 15.3 \\
\hline \multicolumn{5}{|l|}{ Nutritive value } \\
\hline $\mathrm{NE}_{1}, \mathrm{~kJ} / \mathrm{kg} \mathrm{DM}$ & 6683 & 6535 & 6753 & 6650 \\
\hline $\mathrm{PDIE}^{3} \mathrm{~g} / \mathrm{kg}$ DM & 87 & 87 & 99 & 100 \\
\hline PDIN, ${ }^{4} \mathrm{~g} / \mathrm{kg} \mathrm{DM}{ }^{4}$ & 71 & 70 & 96 & 97 \\
\hline $\mathrm{RDP},{ }^{5} \mathrm{~g} / \mathrm{kg} \mathrm{DM}$ & 74 & 76 & 98 & 97 \\
\hline RUP, ${ }^{5} \mathrm{~g} / \mathrm{kg}$ DM & 36 & 39 & 46 & 50 \\
\hline $\mathrm{MP},{ }^{5} \mathrm{~g} / \mathrm{kg} \mathrm{DM}$ & 88 & 84 & 97 & 96 \\
\hline
\end{tabular}

${ }^{1}$ Each diet received $200 \mathrm{~g}$ of a vitamin and trace element premix: $4.5 \% \mathrm{P}$, $20 \% \mathrm{Ca}, 4.5 \% \mathrm{Mg}, 5 \% \mathrm{Na}, 400,000 \mathrm{UI} / \mathrm{kg}$ vitamin $\mathrm{A}, 120,000 \mathrm{UI} / \mathrm{kg}$ vitamin $\mathrm{D}_{3}$, and 1,600 mg/kg vitamin E; Galaphos Midi Duo, CCPA, Aurillac, France.

${ }^{2}$ Cereal-based concentrate: $39 \%$ barley, $46 \%$ wheat, and $15 \%$ corn on a DM basis.

${ }^{3} \mathrm{PDIE}=$ protein digested in the small intestine supplied by rumen undegraded dietary protein and by microbial protein from rumen-fermented OM (INRA, 2007).

${ }^{4} \mathrm{PDIN}=$ protein digested in the small intestine supplied by rumen undegraded dietary protein and by microbial protein from rumen degraded N (INRA, 2007).

${ }^{5}$ Calculated from NRC feed tables (NRC, 2001) using the actual DMI level (on average, 3.04\% BW).

were stored at ambient temperature. All samples were pooled per period. Dry matter and N intake were corrected for losses of volatile compounds (ethanol, ammonia, and acetic and lactic acids) from corn silage during drying (Dulphy et al., 1975).

Ruminal Characteristics. On d 27 and 28, $100 \mathrm{~mL}$ of ruminal fluid was collected by suction through a pipe inserted in the ventral sac just before and 1, 2.5, 5, and $8 \mathrm{~h}$ after the morning feeding. Samples were immediately strained through a $250-\mu \mathrm{m}$-pore nylon filter and maintained on a magnetic stirrer for $\mathrm{pH}$ determination using a digital $\mathrm{pH}$ meter (CG837, $\mathrm{Ag} / \mathrm{AgCl}$ electrode, Schott Gerate, Hofheim, Germany). For all samples, 50 $\mathrm{mL}$ were preserved at $-20^{\circ} \mathrm{C}$ for total $\mathrm{N}$ and nonprotein $\mathrm{N}$ (NPN) determination, $0.8 \mathrm{~mL}$ was added with $0.5 \mathrm{~mL}$ of deproteinizing solution $(1 \mathrm{~g}$ of crotonic acid at $0.05 \mathrm{M}$,
$5 \mathrm{~g}$ of orthophosphoric acid at $0.2 \mathrm{M}$ diluted in $250 \mathrm{~mL}$ of $\mathrm{HCl}$ at $0.5 \mathrm{M}$ ) and stored for $4 \mathrm{~h}$ at $4^{\circ} \mathrm{C}$ before being frozen at $-20^{\circ} \mathrm{C}$ for VFA determination, and $5 \mathrm{~mL}$ were added with $0.5 \mathrm{~mL}$ of $5 \%$ orthophosphoric acid before being frozen at $-20^{\circ} \mathrm{C}$ for ammonia $\left(\mathbf{N H}_{3}\right)$ content determination. Moreover, $3 \mathrm{~mL}$ of the samples collected just before and $2.5 \mathrm{~h}$ after the morning meal were preserved by adding $3 \mathrm{~mL}$ of a methyl green-formalin-salt solution (0.92 $\mathrm{m} M$ methyl green, $0.14 M$ sodium chloride, $35 \mathrm{~mL} / \mathrm{L}$ formaldehyde) and then stored in darkness at room temperature for protozoa counts.

Nutrient Flow. From d 24 to 27, a sample of 0.5\% of the daily fecal excretion was taken, pooled per cow, and stored at $-20^{\circ} \mathrm{C}$ before analysis of the marker used for simultaneous measurement of duodenal and ileal nutrient flows. Duodenal and ileal nutrient flows were determined using $\mathrm{YbCl}_{3}$ as an external marker (Siddons et al., 1985). The $\mathrm{Yb}$ solution was infused continuously into the rumen via the ruminal cannula using a peristaltic pump from d 19 to 27 (i.e., $6 \mathrm{~d}$ before duodenal and ileal samplings) to ensure a steady state before sampling (Owens and Hanson, 1992). A daily quantity of $1.2 \mathrm{~g}$ $\mathrm{Yb}$ dissolved in $2.4 \mathrm{~L}$ of water was infused for each cow. Sixteen duodenal samples of $250 \mathrm{~mL}$ and 16 ileal samples of $100 \mathrm{~mL}$ were collected day and night from d 25 to 27 , providing representative samples of duodenal and ileal contents representing 1.5-h intervals over a day. These samples were pooled per animal and per period and frozen at $-20^{\circ} \mathrm{C}$. To obtain bacterial samples, $2-\mathrm{kg}$ samples representative of ruminal content at the sampling times $(0900,1130$, and $1400 \mathrm{~h})$ were collected on d 24 for 2 cows and on $d 27$ for the other 2 cows. The solid and liquid phases of the ruminal content were separated to obtain samples of solid-adherent bacteria (SAB) and liquid-associated bacteria ( $\mathbf{L A B})$, as described in Bauchart et al. (1990). Bacterial samples were stored at $-20^{\circ} \mathrm{C}$ until chemical analysis.

The ruminal outflow rate of $\mathrm{LAB}$ was estimated from the turnover rate of ruminal fluid, measured 1, 2.5, $5,8,12$, and $24 \mathrm{~h}$ after the end of a continuous infusion of Cr-EDTA ( $1.1 \mathrm{~g} \mathrm{Cr}$ per day for $9 \mathrm{~d}$ ) into the rumen.

Total Tract Digestibility and Nitrogen Balance. Total tract digestibility was determined by daily total feces collection over 6 consecutive days (from d 23 to 28). To separate urine from feces, a flexible pipe connected to a 30 -L flask containing $500 \mathrm{~mL}$ of $10 \%$ sulfuric acid was fixed on each cow. Feces were weighed at $0900 \mathrm{~h}$ and mixed before sampling: an aliquot of $0.5 \%$ of the total daily fecal excretion was pooled per period and per cow and stored at $-20^{\circ} \mathrm{C}$ for subsequent determination of chemical composition. From d 23 to 28, total urine excretion of each cow was weighed at $0900 \mathrm{~h}$, and an aliquot of $1 \%$ was sampled and pooled per cow and stored at $-20^{\circ} \mathrm{C}$ for subsequent $\mathrm{N}$ determination. 
Milk Recording and Sampling. The cows were milked in their stalls twice daily at 0600 and $1600 \mathrm{~h}$. Milk yield was recorded by an automatic infrared flowmeter (Delaval, Elancourt, France). Aliquots (100 mL) of morning and evening milking were taken on d 24, 26, and 28 for fat, protein, lactose, and urea determination.

Chemical Analysis. For each diet ingredient, refusals, duodenal and ileal contents, feces, DM $\left(103^{\circ} \mathrm{C}\right.$ for 24 h), ash $\left(550^{\circ} \mathrm{C}\right.$ for $6 \mathrm{~h}$ ), and $\mathrm{N}$ (Kjeldahl method, AOAC, 1990) were analyzed on fresh samples. The NDF using $\alpha$-amylase and ADF (Van Soest et al., 1991) were analyzed on samples dried for $48 \mathrm{~h}$ at $60^{\circ} \mathrm{C}$ and ground through a 1-mm screen. Silage fermentation characteristics were measured on liquid obtained with a manual press. The $\mathrm{pH}$ was immediately determined with the same $\mathrm{pH}$ meter as described above (CG837, Ag/AgCl electrode, Schott Gerate). Acetic acid and ethanol contents were determined by GLC (Jouany, 1982), lactic acid content was determined by the method described by Noll (1974), and $\mathrm{NH}_{3}$ content was determined by the Conway method (Conway, 1957). Starch was analyzed by spectrophotometry after enzymatic analysis on fresh feeds and refusals and on lyophilized duodenal, ileal, and fecal samples (Faisant et al., 1995). Chemical composition of the total mixed ration offered daily was calculated from the proportion of each ingredient in the diet and the respective chemical composition of each ingredient. Chromium was determined in rumen liquid by atomic absorption spectrophotometry (model 2380 spectrophotometer, PerkinElmer, Bois d'Arcy, France) at a wavelength of $357.9 \mathrm{~nm}$ with an air/acetylene flame directly on supernatant obtained by centrifugation $(5000 \times g$ for $15 \mathrm{~min}$ at room temperature; Michalet-Doreau and Doreau, 2001). Ammonia content of rumen liquid and of duodenal and ileal samples was determined colorimetrically using the automated phenolhypochlorite method (Weatherburn, 1967). Total N was determined on rumen liquid and NPN on the supernatant was obtained by centrifugation $(800 \times g$ for $10 \mathrm{~min}$ at $4{ }^{\circ} \mathrm{C}$ ) after deproteinization ( $3 \mathrm{~mL} 40 \%$ sulfosalicylic acid in $30 \mathrm{~mL}$ rumen liquid), using the Kjeldahl method, as previously described by Doreau et al. (2004). Ytterbium was determined in feces and in duodenal and ileal contents by atomic absorption spectrophotometry (model 2380 spectrophotometer, PerkinElmer) at a wavelength of $398.8 \mathrm{~nm}$ with an acetylene $/ \mathrm{N}_{2} \mathrm{O}$ flame after extraction of the marker from lyophilized samples (Hart and Polan, 1984). Purine and pyrimidine bases were measured with a method adapted from Lassalas et al. (1993). Nucleic acids from lyophilized samples $(0.05 \mathrm{~g}$ of LAB and SAB and $0.2 \mathrm{~g}$ of duodenal contents) were hydrolyzed by perchloric acid $(70 \%)$ at $100^{\circ} \mathrm{C}$ and neutralized by addition of sodium hydroxide $(0.6 N)$. Purine and pyrimidine bases were then quantified using an ultraperformance liquid chromatography method developed in our laboratory. A
$100 \times 2.1 \mathrm{~mm}$ Acquity UPLC BEH, $1.7 \mu \mathrm{m}$ column (Waters, Saint Quentin en Yvelines, France) was used with an isocratic elution method. The solvents used were methanol (4\%) and potassium acetate buffer $50 \mathrm{mM}(96 \%)$. The flow rate was $0.35 \mathrm{~mL} / \mathrm{min}$. The column temperature was maintained at $35^{\circ} \mathrm{C}$ with a column oven (Waters, Saint Quentin en Yvelines, France). The injection volume was $5 \mu \mathrm{L}$. Purine and pyrimidine bases were detected at 254 $\mathrm{nm}$, were identified by comparison of retention times with those of pure standards, and were quantified with an external standard calibration curve. Nitrogen (Dumas method; Etheridge et al., 1998) and ash $\left(550^{\circ} \mathrm{C}\right.$ for $\left.6 \mathrm{~h}\right)$ were measured in lyophilized LAB and SAB. The VFA content of the rumen liquid was determined by GLC using 4-methylvaleric acid as an internal standard. Amino acid content of the duodenal and ileal whole digesta was determined after acid hydrolysis with $\mathrm{HCl} 6 \mathrm{~N}$ at $110^{\circ} \mathrm{C}$ for $24 \mathrm{~h}$ (Poncet and Rémond, 2002). For sulfur AA, the samples were oxidized with performic acid before hydrolysis. Norleucine was used as an internal standard. Immediately after hydrolysis, $\mathrm{HCl}$ was removed under vacuum, and the AA were dissolved in a loading buffer. The AA were separated by ion-exchange chromatography and detected after reaction with ninhydrin (Bio-Tek Instruments A.R.L., St-Quentinen-Yvelines, France). Cysteine and Met were detected as cysteic acid and methionine sulfone, respectively. Milk fat, protein (milk $\mathrm{N} \times 6.38$ ), and lactose concentrations were determined by infrared spectrophotometry (CombiFoss 5000, Foss Electric, Hillerod, Denmark) on morning and evening samples. Milk urea was determined by the dimethylaminobenzaldehyde colorimetric method (Potts, 1967), also on morning and evening samples.

\section{Calculations and Statistical Analysis}

Duodenal and ileal DM flows were calculated as the ratio between the daily amount of $\mathrm{Yb}$ excreted in feces and $\mathrm{Yb}$ content of duodenal and ileal samples, respectively. Daily amounts of DM and $\mathrm{Yb}$ excreted in feces were corrected for the estimated amount of undigestible DM removed by samplings, assuming that samples contained $0.4,0.5$, and $0.7 \mathrm{~g}$ of undigestible $\mathrm{DM} / \mathrm{g} \mathrm{DM}$ at ruminal, duodenal, and ileal levels, respectively. The apparent amount of OM digested in the rumen was estimated by the difference between OM intake and OM duodenal flow. The true amount of OM digested in the rumen (TOMDR) was estimated by adding microbial $\mathrm{OM}$ to the difference between OM intake and OM duodenal flow. The amount and composition of mixed bacteria (MB) were calculated from the average ratio of $\mathrm{LAB}$ and $\mathrm{SAB}$ in the rumen (25:75; Martin and Michalet-Doreau, 1995) and from the outflow rate of these 2 microbial fractions individually measured using Cr-EDTA for LAB and taken as 0.06 for SAB (Doreau and Ottou, 1996). The fractional outflow 
rate of LAB was determined by logarithmic transformation of $\mathrm{Cr}$ concentrations in the rumen fluid, followed by linear regression against time, and expressed as $\mathrm{h}^{-1}$.

Microbial protein synthesis was calculated using MB as the microbial reference sample. Indeed, although samples of LAB are mostly used to estimate microbial protein synthesis and are considered a reference microbial sample because they are easy to isolate, it is now known that $\mathrm{LAB}$ are not representative of the MB leaving the rumen (Doreau and Ottou, 1996). The efficiency of microbial protein synthesis (EMPS) was calculated as the ratio between microbial $\mathrm{N}$ duodenal flow and TOMDR. Ruminal protein balance was calculated as follows:

\section{Ruminal protein balance $=$ \\ $(\mathrm{N}$ intake - duodenal nonammonia $\mathrm{N}$ flow $) \times 6.25$}

\section{DMI}

with $\mathrm{N}$ intake and duodenal nonammonia $\mathrm{N}$ flow being expressed in grams and DMI in kilograms.

Nitrogen recovery was calculated as the sum of fecal $\mathrm{N}$ excretion, urinary $\mathrm{N}$ excretion, and milk $\mathrm{N}$ secretion. Milk fat, protein, lactose, and urea yields were calculated from morning and evening milk yield and composition. The formula used to calculate $4 \%$ fat corrected milk was milk yield $\times(0.4+0.015 \times$ milk fat concentration $)$, with milk yield being expressed in kilograms per day and milk fat concentration in grams per kilogram (INRA, 2007).

Data were analyzed as a $4 \times 4$ Latin square using the MIXED procedure (SAS Inst. Inc., Cary, NC), with mean per animal and treatment as the experimental unit. The statistical model included $\mathrm{N}$ level, energy source, and their interaction as fixed effects and cow as a random effect. When variables were measured at different times of the day $(\mathrm{pH}$, ruminal concentrations, and proportions of VFA and N), data were additionally analyzed using the REPEATED statement within the MIXED procedure of SAS. This statistical model included the effects of $\mathrm{N} \mathrm{lev-}$ el, energy source, time, and their interactions. Each cow was used as the subject. Compound symmetry was used as the covariance structure instead of unstructured and autoregressive symmetry because it provided the best fit to the data on the basis of Akaike and Bayesian information criteria. Significance was declared at a probability value lower than 0.05 . Probability values less than 0.10 were considered trends. When a significant $F$ value was obtained, means were compared using the least squares means procedure (PDIFF option of SAS).

\section{RESULTS}

\section{Rumen Fermentation}

The average ruminal concentration of $\mathrm{NH}_{3}-\mathrm{N}$ was lower at the low $\mathrm{N}$ level than at the high $\mathrm{N}$ level $(P=$ $0.010)$ and lower with high-starch diets than with highfiber diets $(P=0.008$; Table 2$)$. The ruminal concentration of total soluble $\mathrm{N}$ was lower $(P=0.009)$ at the low $\mathrm{N}$ level than at the high $\mathrm{N}$ level (Table 2). The average ruminal concentration of protein soluble $\mathrm{N}$ was lower $(P=0.011)$ at the low $\mathrm{N}$ level than at the high $\mathrm{N}$ level (Table 2). The average ruminal concentration of

Table 2. Average $\mathrm{N}$ fractions in ruminal liquid, ruminal $\mathrm{pH}$, and VFA sampled just before and 1, 2.5, 5 , and $8 \mathrm{~h}$ after the morning feeding and average ruminal protozoa population sampled just before and $2.5 \mathrm{~h}$ after the morning feeding of cows receiving high-starch or high-fiber concentrate at a low or high $\mathrm{N}$ level

\begin{tabular}{|c|c|c|c|c|c|c|c|c|c|}
\hline \multirow[b]{2}{*}{ Item } & \multirow[b]{2}{*}{$n$} & \multicolumn{2}{|c|}{ Low N } & \multicolumn{2}{|c|}{ High N } & \multirow[b]{2}{*}{ SEM } & \multicolumn{3}{|c|}{$P$-values } \\
\hline & & Starch & Fiber & Starch & Fiber & & $\mathrm{N}$ & $\mathrm{E}$ & $\mathrm{N} \times \mathrm{E}$ \\
\hline $\mathrm{NH}_{3}-\mathrm{N}, \mathrm{mg} / \mathrm{L}$ & 80 & 24.6 & 99.7 & 96.4 & 124.1 & 11.67 & 0.010 & 0.008 & 0.06 \\
\hline Total soluble N, mg/L & 80 & 448 & 547 & 655 & 732 & 50.8 & 0.009 & 0.07 & 0.76 \\
\hline Protein soluble N, mg/L & 80 & 272 & 266 & 381 & 448 & 28.5 & 0.011 & 0.33 & 0.26 \\
\hline Non-protein soluble $\mathrm{N}, \mathrm{mg} / \mathrm{L}$ & 80 & 176 & 281 & 274 & 284 & 29.4 & 0.06 & 0.043 & 0.07 \\
\hline NPNA soluble $\mathrm{N},{ }^{1} \mathrm{mg} / \mathrm{L}$ & 80 & 151 & 181 & 177 & 160 & 20.9 & 0.86 & 0.67 & 0.19 \\
\hline $\mathrm{pH}$ & 80 & 6.4 & 6.6 & 6.5 & 6.5 & 0.08 & 0.95 & 0.09 & 0.31 \\
\hline Total VFA, mM & 80 & 96.7 & 102.4 & 101.0 & 104.9 & 4.72 & 0.24 & 0.13 & 0.74 \\
\hline Acetate, $\mathrm{mol} / 100 \mathrm{~mol}$ & 80 & 65.5 & 67.6 & 65.6 & 67.7 & 0.94 & 0.94 & 0.06 & 1.00 \\
\hline Propionate, mol/100 mol & 80 & 16.8 & 18.3 & 17.4 & 17.9 & 0.60 & 0.79 & 0.09 & 0.27 \\
\hline Isobutyrate, $\mathrm{mol} / 100 \mathrm{~mol}$ & 80 & 0.64 & 0.66 & 0.83 & 0.77 & 0.066 & 0.014 & 0.54 & 0.15 \\
\hline Butyrate, mol/100 mol & 80 & 13.9 & 10.8 & 12.5 & 10.8 & 1.02 & 0.15 & 0.007 & 0.15 \\
\hline Isovalerate, $\mathrm{mol} / 100 \mathrm{~mol}$ & 80 & 1.06 & 1.91 & 1.45 & 1.23 & 0.161 & 0.010 & 0.05 & 0.38 \\
\hline Valerate, $\mathrm{mol} / 100 \mathrm{~mol}$ & 80 & 1.45 & 1.09 & 1.28 & 1.11 & 0.114 & 0.45 & 0.06 & 0.38 \\
\hline Total protozoa, $10^{3} / \mathrm{mL}$ & 32 & 112 & 172 & 183 & 216 & 44.2 & 0.27 & 0.36 & 0.77 \\
\hline Ophryoscolecidae, $10^{3} / \mathrm{mL}$ & 32 & 110 & 167 & 179 & 210 & 44.3 & 0.28 & 0.38 & 0.78 \\
\hline Isotrichidae, $10^{3} / \mathrm{mL}$ & 32 & 1.91 & 4.70 & 4.76 & 5.20 & 1.40 & 0.15 & 0.16 & 0.27 \\
\hline
\end{tabular}

${ }^{1} \mathrm{NPNA}=$ nonprotein nonammonia. 
Table 3. Nitrogen intake, duodenal $\mathrm{N}$ flow, microbial protein synthesis, and efficiency of microbial protein synthesis in cows receiving high-starch or high-fiber concentrate at a low or high $\mathrm{N}$ level

\begin{tabular}{|c|c|c|c|c|c|c|c|c|}
\hline \multirow[b]{2}{*}{ Item $^{1}$} & \multicolumn{2}{|c|}{ Low $\mathrm{N}$} & \multicolumn{2}{|c|}{ High $\mathrm{N}$} & \multirow[b]{2}{*}{ SEM } & \multicolumn{3}{|c|}{$P$-values } \\
\hline & Starch & Fiber & Starch & Fiber & & $\mathrm{N}$ & $\mathrm{E}$ & $\mathrm{N} \times \mathrm{E}$ \\
\hline $\mathrm{N}$ intake, $\mathrm{g} / \mathrm{d}$ & 352 & 360 & 453 & 471 & 10.9 & $<0.001$ & 0.103 & 0.48 \\
\hline $\mathrm{N}, \mathrm{g} / \mathrm{d}$ & 397 & 355 & 519 & 455 & 28.8 & 0.001 & 0.06 & 0.67 \\
\hline Nonammonia $\mathrm{N}, \mathrm{g} / \mathrm{d}$ & 390 & 347 & 500 & 437 & 27.9 & 0.002 & 0.05 & 0.70 \\
\hline Ruminal protein balance, ${ }^{2} \mathrm{~g} \mathrm{CP} / \mathrm{kg}$ DMI & -12.2 & 3.9 & -14.6 & 10.6 & 6.98 & 0.77 & 0.016 & 0.53 \\
\hline EMPS,${ }^{3,4}$ g N/kg OM fermented & 26.0 & 20.6 & 28.1 & 23.9 & 2.45 & 0.29 & 0.08 & 0.80 \\
\hline
\end{tabular}

nonprotein soluble $\mathrm{N}$ was greater with high-fiber diets than with high-starch diets $(P=0.043)$. The average ruminal concentration of nonprotein, nonammonia soluble $\mathrm{N}$ was not modified by the dietary treatments $(P=0.86$ and 0.67 for the effect of the level of $\mathrm{N}$ and the energy source, respectively).

Rumen $\mathrm{pH}$ did not differ between low and high $\mathrm{N}$ levels $(P=0.95)$ but tended to be greater with high-fiber diets than with high-starch diets $(P=0.09$; Table 2$)$. Average values for molar concentration of total VFA and molar percentages of acetate, propionate, and valerate in the rumen liquid were similar between treatments (Table 2). The average molar concentration of butyrate was lower with high-fiber diets than with high-starch diets $(P$ $=0.007)$. Average molar percentages of isobutyrate and isovalerate were lower $(P=0.014$ and 0.010 , respectively) at the low $\mathrm{N}$ level than the high $\mathrm{N}$ level.

\section{Nutrient Flow and Digestibility}

Duodenal flow of $\mathrm{N}$ decreased with the $\mathrm{N}$ level of the diet $(P<0.001)$ and tended to be greater with highstarch diets than with high-fiber diets $(P=0.06$; Table 3). Nonammonia $\mathrm{N}$ duodenal flow increased with the $\mathrm{N}$ level of the diet $(P<0.001)$, whereas it decreased from high-starch to high-fiber diets $(P=0.05)$. Ruminal protein balance was not significantly modified by the N level of the diet $(P=0.77)$ but was greater with high-fiber diets than with high-starch diets $(P=0.016)$.

When the $\mathrm{N}$ content of the diet decreased, the $\mathrm{N}$ content of LAB and SAB decreased from $7.5 \%$ to $7.2 \%$ of $\mathrm{DM}$ and $6.8 \%$ to $6.5 \%$ of $\mathrm{DM}$ for $\mathrm{LAB}$ and $\mathrm{SAB}$, respectively $(P=0.004$ and 0.003 , respectively; data not shown). At the same time, the N content of LAB and $\mathrm{SAB}$ was greater $(P=0.005$ and 0.030$)$ with high-fiber diets (7.5\% and $6.7 \%$ of DM for $\mathrm{LAB}$ and $\mathrm{SAB}$, respectively) than with high-starch diets $(7.2 \%$ and $6.5 \%$ of $\mathrm{DM}$ for
$\mathrm{LAB}$ and $\mathrm{SAB}$, respectively). Microbial duodenal $\mathrm{N}$ flow was not significantly modified by the $\mathrm{N}$ level of the diet $(P=0.19)$ or by the energy source of the $\operatorname{diet}(P=0.11)$ when MB was taken as reference (Table 3 ) but tended to be greater at the high $\mathrm{N}$ level $(P=0.07)$ and with highstarch diets $(P=0.08)$ when LAB was taken as reference (data not shown). Nonmicrobial, nonammonia $\mathrm{N}$ calculated using MB flow was less at the low $\mathrm{N}$ level than the high $\mathrm{N}$ level $(P=0.05$; Table 3$)$. The proportion of microbial $\mathrm{N}$ flow in nonammonia $\mathrm{N}$ flow differed widely according to the method of calculation, on average $73 \%$ with MB vs. $55 \%$ with LAB (data not shown).

Duodenal flow of total AA was lower with low-N diets than high-N diets $(P=0.003$; Table 4$)$. At the same time, the amounts of essential AA and nonessential AA were lower ( $P=0.001$ and 0.007 , respectively) with low$\mathrm{N}$ diets than with high-N diets. Duodenal flow of Arg, His, Ile, Leu, Lys, Phe, Thr, and Val was greater with high-N diets than low-N diets $(P<0.05)$, whereas duodenal flow of Met was not modified by the experimental treatment $(P$ $=0.14$ and 0.11 for the effect of the $\mathrm{N}$ level and the energy source, respectively). Apparent small intestine digestibility of individual essential AA did not vary among treatments (Table 4). Apparent small intestine digestibility of Ile was greater with high-N diets than low-N diets $(P=0.05)$.

The amount of OM apparently digested in the rumen and TOMDR calculated using MB did not vary between low and high $\mathrm{N}$ levels ( $P=0.61$ and 0.84 , respectively) or between high-fiber and high-starch diets $(P=0.19$ and 0.75 , respectively), even when expressed relative to OM intake (Table 5). The efficiency of microbial protein synthesis did not vary with dietary N level $(P=0.29)$ but tended to be greater $(P=0.08)$ with high-starch diets than with high-fiber diets (Table 3).

As expected, the amount of NDF digested in the rumen was greater $(P<0.001)$ with high-fiber diets than with high-starch diets because of both greater NDF in- 
Table 4. Amino acid duodenal flow and AA intestinal digestibility in cows receiving high-starch or high-fiber concentrate at a low or high $\mathrm{N}$ level

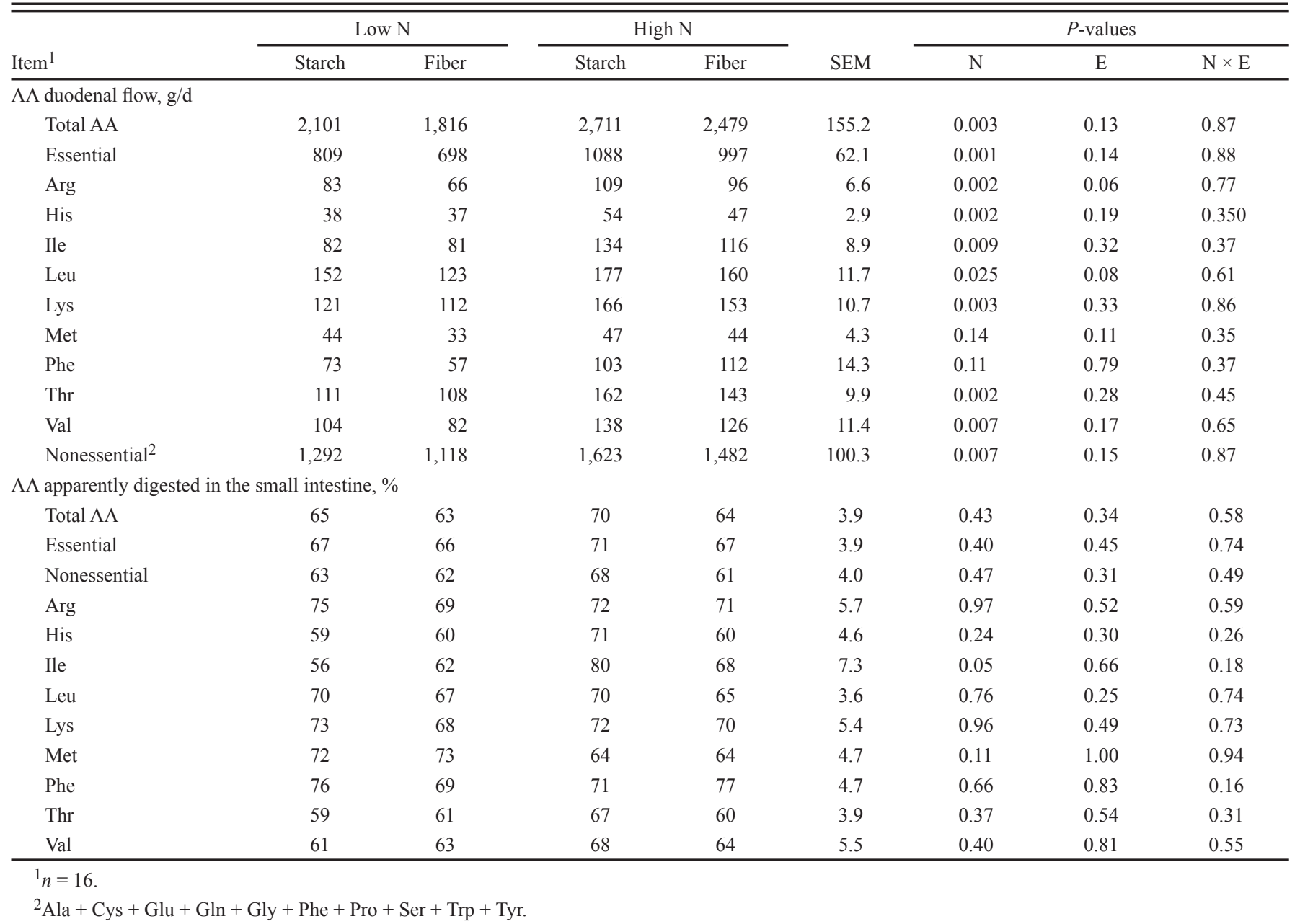

take $(P<0.001)$ and greater NDF ruminal digestibility $(P=0.015$; Table 5$)$. The amount of starch digested in the rumen was greater with high-starch diets than with high-fiber diets $(P<0.001)$. Similarly, ruminal digestibility of starch was greater with high-starch diets than with high-fiber diets $(P=0.018)$. At the same time, intestinal digestibility of starch did not vary between low and high $\mathrm{N}$ levels $(P=0.94)$ or between high-fiber and high-starch diets $(P=0.84)$.

Apparent total tract digestibility was lower at low $\mathrm{N}$ than at high $\mathrm{N}$ for $\mathrm{DM}$ and $\mathrm{OM}(P=0.008$ and 0.006 , respectively; Table 6). There were significant interactions between $\mathrm{N}$ level and dietary energy source for NDF and ADF total tract digestibility $(P=0.014$ and 0.05 , respectively). The total tract digestibility of starch tended to be greater with high-starch diets than with high-fiber diets $(P=0.08)$.

\section{Milk Production and N Partitioning}

There was no significant interaction between $\mathrm{N}$ level and the dietary energy source for any of the milk pro- duction and $\mathrm{N}$ partitioning parameters (Table 7). Milk yield was lower at the low $\mathrm{N}$ level than the high $\mathrm{N}$ level $(P=0.002)$. No effect of the $\mathrm{N}$ level of the diet was observed on milk fat, milk protein, and milk lactose contents $(P=0.10,0.66$, and 0.13 , respectively). Milk urea $\mathrm{N}$ content was lower at the low $\mathrm{N}$ than the high $\mathrm{N}$ level $(P=0.004)$. Milk protein content was greater with highstarch diets than with high-fiber diets $(P=0.013)$. When increasing the $\mathrm{N}$ level of the diet, $4 \%$ fat corrected milk increased $(P=0.006)$, whereas it was lower with highstarch diets than with high-fiber diets $(P=0.015)$. When expressed as daily amount secreted, milk fat tended to be lower with low-N diets than high-N diets $(P=0.09)$ and lower with high-starch diets than high-fiber diets $(P$ $=0.06)$. Milk lactose and milk protein were lower at the low $\mathrm{N}$ level than at the high $\mathrm{N}$ level $(P=0.002$ and $P=$ 0.013 , respectively).

Fecal $\mathrm{N}$ excretion was unaffected by the $\mathrm{N}$ level of the diet $(P=0.24)$ or by the energy source $(P=0.17$; Table 6). Daily output of $\mathrm{N}$ in urine was lower at the low $\mathrm{N}$ level than the high $\mathrm{N}$ level $(P<0.001)$. The decrease in urinary $\mathrm{N}$ observed with low-N diets was related to a 
Table 5. Organic matter, NDF, and starch intake and ruminal digestion and starch intestinal digestion of cows receiving high-starch or high-fiber concentrate at a low or high $\mathrm{N}$ level

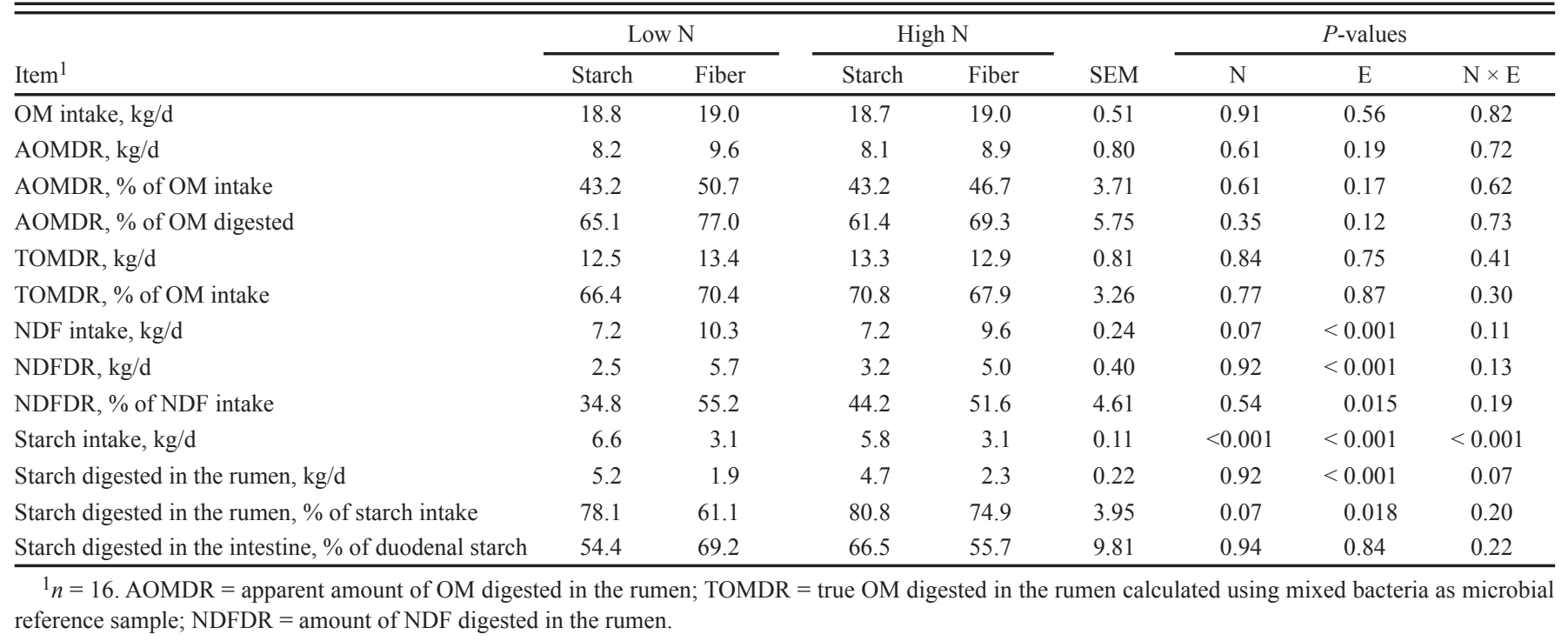

decrease in both the volume of urine $(P=0.021$, data not shown) and urine $\mathrm{N}$ concentration $(P<0.001$, data not shown). The daily secretion of $\mathrm{N}$ in milk was lower at the low $\mathrm{N}$ level than the high $\mathrm{N}$ level $(P=0.013)$.

When expressed as a percentage of $\mathrm{N}$ intake, urinary $\mathrm{N}$ excretion was lower at the low $\mathrm{N}$ level than the high $\mathrm{N}$ level (16.0\% vs. $25.5 \%$, respectively; $P<0.001$, data not shown). In contrast, milk $\mathrm{N}$ secretion and fecal $\mathrm{N}$ excretion were greater $(P=0.003$ and $P<0.001)$ at the low $\mathrm{N}$ level than the high $\mathrm{N}$ level $(28.9 \%$ vs. $25.0 \%$ for milk N secretion and $43.0 \%$ vs. $34.9 \%$ for fecal $\mathrm{N}$ excretion; $P$ $<0.01$, data not shown). The resulting $\mathrm{N}$ secretion was not significantly modified by the dietary treatments $(P$ $=0.18$ and 0.72 for the effect of the level of $\mathrm{N}$ and the energy source, respectively).

\section{DISCUSSION}

\section{Ruminal Digestion of OM, Fiber, and Starch}

Both ruminal and total tract digestibility of NDF were greater with high-fiber diets than with high-starch diets. This can be related both to the high digestibility of the NDF in soybean hulls $(79 \%$ estimated from INRA, 2007) and to an expected decrease in digestibility of the forage cell wall with high-starch diets (Nozière et al., 1996). Here, the uncertainties of NDF measurements in duodenal digesta may explain the slightly greater ruminal than fecal digestibility of NDF $(55.2 \%$ vs. $54.7 \%)$ with the low-N, high-fiber diet, but most of the NDF digestion (around $90 \%$ on average for the 4 diets) oc-

Table 6. Total tract digestibility and $\mathrm{N}$ balance of cows receiving high-starch or high-fiber concentrate at a low or high $\mathrm{N}$ level

\begin{tabular}{|c|c|c|c|c|c|c|c|c|}
\hline \multirow[b]{2}{*}{ Item $^{1}$} & \multicolumn{2}{|c|}{ Low $\mathrm{N}$} & \multicolumn{2}{|c|}{ High $N$} & \multirow[b]{2}{*}{ SEM } & \multicolumn{3}{|c|}{$P$-values } \\
\hline & Starch & Fiber & Starch & Fiber & & $\mathrm{N}$ & $\mathrm{E}$ & $\mathrm{N} \times \mathrm{E}$ \\
\hline \multicolumn{9}{|c|}{ Total tract apparent digestibility, $\%$} \\
\hline $\mathrm{OM}$ & 66.4 & 65.8 & 70.5 & 67.7 & 0.99 & 0.006 & 0.08 & 0.24 \\
\hline NDF & 38.5 & 54.7 & 49.0 & 55.5 & 1.79 & 0.007 & $<0.001$ & 0.014 \\
\hline $\mathrm{ADF}$ & 33.4 & 50.6 & 42.7 & 50.8 & 2.30 & 0.044 & $<0.001$ & 0.051 \\
\hline \multicolumn{9}{|l|}{$\mathrm{N}$ balance } \\
\hline N intake, g/d & 352 & 360 & 453 & 471 & 10.9 & $<0.001$ & 0.103 & 0.48 \\
\hline Fecal N, g/d & 149 & 157 & 155 & 168 & 6.8 & 0.24 & 0.17 & 0.68 \\
\hline Urinary $\mathrm{N}, \mathrm{g} / \mathrm{d}$ & 53 & 61 & 115 & 121 & 8.0 & $<0.001$ & 0.37 & 0.85 \\
\hline Milk N, g/d & 105 & 101 & 117 & 114 & 6.4 & 0.013 & 0.37 & 0.85 \\
\hline $\mathrm{N}$ excretion, ${ }^{2} \% \mathrm{~N}$ intake & 87.2 & 88.6 & 85.4 & 85.6 & 1.70 & 0.18 & 0.72 & 0.74 \\
\hline
\end{tabular}


Table 7. Dry matter intake and milk secretion of cows receiving high-starch or high-fiber concentrate at a low or high N level

\begin{tabular}{|c|c|c|c|c|c|c|c|c|}
\hline \multirow[b]{2}{*}{ Item $^{1}$} & \multicolumn{2}{|c|}{ Low $\mathrm{N}$} & \multicolumn{2}{|c|}{ High $\mathrm{N}$} & \multirow[b]{2}{*}{ SEM } & \multicolumn{3}{|c|}{$P$-values } \\
\hline & Starch & Fiber & Starch & Fiber & & $\mathrm{N}$ & $\mathrm{E}$ & $\mathrm{N} \times \mathrm{E}$ \\
\hline DMI, kg/d & 20.0 & 20.3 & 19.9 & 20.4 & 0.54 & 0.94 & 0.30 & 0.86 \\
\hline Milk fat content, $\mathrm{g} / \mathrm{kg}$ & 36.0 & 37.8 & 35.1 & 38.6 & 2.47 & 1.00 & 0.31 & 0.73 \\
\hline Milk protein content, ${ }^{2} \mathrm{~g} / \mathrm{kg}$ & 30.0 & 28.4 & 30.7 & 28.2 & 0.97 & 0.66 & 0.013 & 0.55 \\
\hline Milk lactose content, $\mathrm{g} / \mathrm{kg}$ & 48.1 & 49.0 & 49.2 & 49.4 & 0.61 & 0.13 & 0.31 & 0.48 \\
\hline Milk protein, $\mathrm{g} / \mathrm{d}$ & 672 & 643 & 744 & 725 & 40.7 & 0.013 & 0.37 & 0.85 \\
\hline Milk lactose, $\mathrm{g} / \mathrm{d}$ & 1,079 & 1,112 & 1,187 & 1,270 & 64.4 & 0.002 & 0.09 & 0.43 \\
\hline $4 \%$ fat corrected milk, ${ }^{3} \mathrm{~kg} / \mathrm{d}$ & 20.9 & 21.9 & 22.3 & 25.2 & 0.65 & 0.006 & 0.015 & 0.20 \\
\hline Milk urea $\mathrm{N}$ content, mg/dL & 5.46 & 7.98 & 10.40 & 12.83 & 1.493 & 0.004 & 0.11 & 0.90 \\
\hline
\end{tabular}

curred in the rumen, which is in line with a limited contribution of the hindgut to NDF digestion under most diets (Sauvant and Van Milgen, 1995). The decrease in N dietary content induced a decrease in NDF digestibility under high-starch diets (36\% NDF) but not with highfiber diets (49\% NDF, significant interaction). A similar trend was numerically observed at the ruminal level, although it failed to reach statistical significance. Similar trends at the ruminal level were observed by Peyraud et al. (1997) in dairy cows and Valkeners et al. (2008) in growing bulls fed low-NDF diets (35\% of DM). This suggests that NDF digestion is more sensitive to low $\mathrm{CP}$ level when it is first impaired by high-starch concentrate. Also, it could be suggested that there is a larger need for $\mathrm{N}$ with starch for microbial growth, which cannot be detected statistically because of the lack of accuracy of the marker method.

Decreasing dietary CP level did not significantly affect the total tract digestion of starch. At the total tract level, Doreau et al. (1990), in both dry and lactating cows, and Agle et al. (2010), in lactating cows, observed a slight decrease in total tract starch digestibility with the low-N diets, in line with the numerical differences (3 points) observed in the present work. At the rumen level, we also observed a numerical decrease in starch digestion at the low $\mathrm{N}$ level with high-fiber diets but not with high-starch diets. This is in line with Valkeners et al. (2008), who reported that a N shortage did not affect ruminal starch digestibility in growing bulls fed low-NDF diets (35\%). Taken together, these results suggest that with low-starch diets, the amylolytic microbial population is more sensitive than the cellulolytic population to a $\mathrm{N}$ shortage. However, starch escaping ruminal digestion was efficiently digested in the intestine, allowing an almost complete compensation of starch digestion.

\section{Nitrogen Digestion and Metabolism}

In the present experiment, decreasing the dietary $\mathrm{N}$ level only slightly decreased the microbial $\mathrm{N}$ flow (but significantly using LAB as the reference sample), and the decrease in the nonmicrobial, nonammonia flow reaching the small intestine was mainly due to the nonmicrobial fraction. This is in line with the literature review on dairy cows by Clark et al. (1992), who reported that the amount of microbial $\mathrm{N}$ entering the small intestine was not significantly modified by dietary $\mathrm{N}$ content. The low extent of the variation in microbial $\mathrm{N}$ flow, although the supply of rumen-degradable $\mathrm{N}$ was assumed to be limiting for microbial $\mathrm{N}$ synthesis, could be partly related to the uncertainties related to the digesta flow measurements using a single marker method. However, similar results have also been reported by others in dairy cows (Peyraud et al., 1997) and bulls (Valkeners et al., 2008). This implies that the shortage in degradable $\mathrm{N}$ either improved $\mathrm{N}$ recycling or improved the EMPS or both. These 2 points are discussed in turn below.

Rumen protein balance is generally considered as an indicator of $\mathrm{N}$ recycling in the rumen. Here, we found that rumen protein balance was not modified by dietary $\mathrm{N}$ level, suggesting that the $\mathrm{N}$ shortage was not compensated for by $\mathrm{N}$ recycling. This contrasts with what is commonly reported (Lapierre and Lobley, 2001). However, rumen protein balance shifted from a negative balance with high-starch diets to a positive balance with highfiber diets, suggesting that recycling could be improved with starch. Previous work has already evidenced the ability of the rumen wall to regulate in the short-term the net transfer of urea from blood to lumen in response to the ratio of degradable $\mathrm{N}$ to fermentable carbohydrate (Rémond et al., 2009), and this ability may explain the greater recycling with starch. The low $\mathrm{NH}_{3}-\mathrm{N}$ concentra- 
tion obtained with the low- $\mathrm{N}$, high-starch diet (averaging $24.6 \mathrm{mg} / \mathrm{L}$ over the postprandial period) suggested that a low $\mathrm{NH}_{3}-\mathrm{N}$ concentration in the rumen did not impair microbial growth. Similar results $\left(\mathrm{NH}_{3}-\mathrm{N}<40 \mathrm{mg} / \mathrm{L}\right)$ have previously been reported in dairy cows fed diets at 11\% CP (Doreau et al., 1990; Klusmeyer et al., 1990; Peyraud et al., 1997) and even up to $15 \%$ to $17 \%$ CP (Mc Carthy et al., 1989; Yang et al., 1997), without a change in microbial synthesis (Mc Carthy et al., 1989; Peyraud et al., 1997; Yang et al., 1997). It is noticeable that the ruminal digestibility of NDF was depressed with the low $\mathrm{NH}_{3}-\mathrm{N}$ concentration obtained with the low-N, highstarch diet even though the microbial growth was not impaired. Again, although methodological uncertainties could partly explain this apparent discrepancy, this result is in line with Hoover (1986), who reported that maximum microbial growth could be achieved with a lower $\mathrm{NH}_{3}$ level than that required to maximize cellulolysis.

The EMPS was unaffected by the N level. Similarly, no variation in EMPS when decreasing the dietary level of degradable $\mathrm{N}$ up to $11 \% \mathrm{CP}$ was reported by Peyraud et al. (1997) in dairy cows and by Valkeners et al. (2008) in bulls, and a nonsignificant trend for a decrease in EMPS has been found by Aschemann et al. (2012b). More generally, among ruminants, EMPS does not appear to be closely related to dietary CP level, but rather to rumen protein balance as well as to TOMDR and passage rates (Sauvant and Nozière, 2011), as also observed in the present study, where rumen protein balance increased and EMPS decreased between high-starch and high-fiber diets at a similar CP level.

\section{Nitrogen Partitioning between Feces, Urine, and Milk}

Milk protein yield decreased when decreasing the $\mathrm{N}$ level of the diet, but the efficiency of dietary $\mathrm{N}$ conversion into milk $\mathrm{N}$ increased. Although the present work concerns short-term measurements for only 4 animals, this pattern of increase in efficiency of dietary $\mathrm{N}$ conversion into milk when decreasing dietary $\mathrm{N}$ input level is commonly reported in the literature (Klusmeyer et al., 1990; Olmos Colmenero and Broderick, 2006; Brun-Lafleur et al., 2010) when DMI remains constant. Nevertheless, milk production was impaired (decreasing by 2.3 $\mathrm{kg} / \mathrm{d}$ ) when decreasing the $\mathrm{N}$ level of the diet. This result is consistent with previous experiments by Kalscheur et al. (2006), Cyriac et al. (2008), and Cantalapiedra-Hijar et al. (2011) but not with those of Peyraud et al. (1997), Olmos Colmenero and Broderick (2006), Agle et al. (2010), and Aschemann et al. (2012a) with a decrease until a similar $\mathrm{N}$ level in the diet. The reason for the different patterns of response between these experiments is unclear. The decrease in milk yield with the low-N diets in our experiment may be due both to the decrease in diet digestibility without a change in feed intake and to the shortage in digestible AA, at least for limiting AA.

Here, decreasing the $\mathrm{N}$ level of the diet results in a decrease in $\mathrm{N}$ excretion in manure, and this decrease was mainly related to a decrease in urinary $\mathrm{N}$ excretion, whereas fecal $\mathrm{N}$ excretion remained constant. The decrease in urinary $\mathrm{N}$ when decreasing the diet level of degradable $\mathrm{N}$ is a classical result already widely reported by others (Peyraud et al., 1997; Agle et al., 2010; Edouard et al., 2011) with comparable differences in rumen-degradable $\mathrm{N}$ level of the diet. Conversely, the literature reports contrasting results on the effect of dietary $\mathrm{N}$ level on fecal $\mathrm{N}$ excretion. Some authors reported a decrease in fecal $\mathrm{N}$ excretion when decreasing dietary $\mathrm{N}$ level (Kalscheur et al., 2006; Olmos Colmenero and Broderick, 2006; Cyriac et al., 2008), whereas others have reported no significant effect (Peyraud et al., 1997; Agle et al., 2010; Edouard et al., 2011), as was the case in our trial. The differences in response of fecal $\mathrm{N}$ to a decrease in dietary $\mathrm{N}$ may be due to differences in ruminal $\mathrm{N}$ metabolism; in our experiment, apparent total tract digestibility of $\mathrm{N}$, which generally depends on ruminal $\mathrm{N}$ balance, was lower for low-N diets. Kebreab et al. (2001), using a database made from $5 \mathrm{~N}$ balance experiments built to investigate the relationships between dietary $\mathrm{N}$ and $\mathrm{N}$ excretion in urine, feces, and milk, reported that urinary $\mathrm{N}$ excretion was positively and exponentially correlated with dietary N. However, in this database, fecal $\mathrm{N}$ excretion and milk $\mathrm{N}$ secretion were linearly but poorly affected (by less than $20 \%$ ) by decreasing dietary $\mathrm{N}$, thus illustrating, as in the present experiment, that milk $\mathrm{N}$ secretion has priority for metabolic use of absorbed $\mathrm{N}$.

Whatever the dietary treatment, the $\mathrm{N}$ balance of the animal (i.e., $\mathrm{N}$ intake - milk $\mathrm{N}-$ urinary $\mathrm{N}-$ fecal $\mathrm{N}$ ) was positive, suggesting a high level of $\mathrm{N}$ retention and an increase in the BW of the cows. However, this is not the case in this study, and our results suggest an overestimation of the N balance. Spanghero and Kowalski (1997), in a critical analysis of $\mathrm{N}$ balance experiments with lactating cows, reported that most of the studies with high-producing dairy cows overestimate $\mathrm{N}$ balance. These authors have identified 4 main sources of error in $\mathrm{N}$ balance trial that may cause this overestimation: underestimation of fecal $\mathrm{N}$, volatile $\mathrm{N}$ loss from the urine container, dermal and scurf losses, and inaccuracy of milk $\mathrm{N}$ content determination. However, in the present experiment, it was not possible to know what fraction of $\mathrm{N}$ output was underestimated.

\section{Conclusions}

Reducing dietary $\mathrm{N}$ level caused decreases in the digestibility of OM and in the flow of AA absorbed. This decrease was primarily related to a decrease in AA from the nonmicrobial fraction, whereas the microbial flow 
was only slightly and not significantly modified. Moreover, although production data should be considered with caution in such short-term digestion trials, there was a concomitant increase in the efficiency of use of absorbed $\mathrm{N}$ that induced a moderate drop in milk protein secretion but allowed a sharp decline in $\mathrm{N}$ excretion in urine. In our study, shifting the energy source of the diet from fiber to starch only slightly and not significantly increased the flow of AA apparently absorbed. Our results do, however, suggest a better recycling of $\mathrm{N}$ and a better use of $\mathrm{NH}_{3}$ with high-starch than with high-fiber diets.

These results highlight, first, that the reduction of fermentable $\mathrm{N}$ favored the ability of animals to recycle $\mathrm{N}$ and, second, that absorbed AA would primarily be used by the mammary gland, suggesting that the microbial ecosystem is highly resilient. A compromise between reduced environmental release of $\mathrm{N}$ and increased efficiency of animal performance has to be found.

\section{LITERATURE CITED}

Agle, M., A. H. Hristov, S. Zaman, C. Schneider, P. Ndegwa, and V. K. Vaddella. 2010. The effects of ruminally degraded protein on rumen fermentation and ammonia losses from manure in dairy cows. J. Dairy. Sci. 93:1625-1637.

AOAC. 1990. Official methods and analysis. Vol. 1. 15th ed. Assoc. Off. Anal. Chem., Arlington, VA.

Aschemann, M., P. Lebzien, L. Hüther, S. Döll, K. H. Südekum, and S. Dänicke. 2012a. Effect of niacin supplementation on digestibility, nitrogen utilisation and milk and blood variables in lactating dairy cows fed a diet with a negative rumen nitrogen balance. Arch. Anim. Nutr. 66:200-214.

Aschemann, M., P. Lebzien, L. Hüther, K. H. Südekum, and S. Dänicke. 2012b. Effect of niacin supplementation on rumen fermentation parameters and nutrient flow at the duodenum in lactating dairy cows fed a diet with a negative rumen nitrogen balance. Arch. Anim. Nutr. 66:303-318.

Bach, A., S. Calsamiglia, and M. D. Stern. 2005. Nitrogen metabolism in the rumen. J. Dairy Sci. 88(E. Suppl.):E9-E21.

Bauchart, D., F. Legay-Carmier, M. Doreau, and B. Gaillard. 1990. Lipid metabolism of liquid-associated and solid-adherent bacteria in rumen contents of dairy cows offered lipid-supplemented diets. Br. J. Nutr. 63:563-578.

Belanche, A., M. Doreau, J. E. Edwards, J. M. Moorby, E. Pinloche, and C. J. Newbold. 2012. Shifts in the rumen microbiota due to the type of carbohydrate and level of protein ingested by dairy cattle are associated with rumen fermentation. J. Nutr. 142:1684-1692.

Brun-Lafleur, L., L. Delaby, F. Husson, and P. Faverdin. 2010. Predicting energy $\times$ protein interaction on milk yield and composition in dairy cows. J. Dairy Sci. 93:4128-4143.

Calsamiglia, S., A. Ferret, C. K. Reynolds, N. B. Kristensen, and A. M. Van Vuuren. 2010. Strategies for optimizing nitrogen use by ruminants. Animal 4:1184-1196.

Canadian Council on Animal Care. 1993. Guide to the care and use of experimental animals. Vol. 1. 2nd ed. Can. Counc. Anim. Care, Ottawa.
Cantalapiedra-Hijar, G., J. L. Peyraud, S. Lemosquet, P. Nozière, and I. Ortigues-Marty. 2011. Conversion of dietary N into milk $\mathrm{N}$ may be enhanced by the energy source in isoenergetic diets. In: Proc. 8th Int. Symp. Nutr. Herbivores, Aberystwyth, UK. p. 493.

Clark, J. H., T. H. Klusmeyer, and M. R. Cameron. 1992. Microbial protein synthesis and flows of nitrogen fractions to the duodenum of dairy cows. J. Dairy Sci. 75:2304-2323.

Conway, E. J. 1957. Microdiffusion analysis and volumetric error. Lockwood, London.

Cyriac, J., G. Ruis, M. L. McGilliard, R. E. Pearson, B. J. Bequette, and M. D. Hanigan. 2008. Lactating performance of mid-lactation dairy cows fed ruminally degradable protein at concentrations lower than national research council recommendations. J. Dairy Sci. 91:4704-4713.

Doreau, M., A. Delacroix, J. P. Jouany, C. Durier, and B. Rémond. 1990. The influence of physiological state and dietary nitrogen supply on digestion in the dairy cow. J. Anim. Sci. 68:38533860.

Doreau, M., B. Michalet-Doreau, and G. Bechet. 2004. Effect of underfeeding on digestion in cows. Interaction with rumen degradable N supply. Livest. Prod. Sci. 88:33-41.

Doreau, M., and J. F. Ottou. 1996. Influence of niacin supplementation on in vivo digestibility and ruminal digestion in dairy cows. J. Dairy Sci. 79:2247-2254.

Doreau, M., and B. Rémond. 1982. Feeding behaviour, and digestibility of a diet of constant composition in dairy cows at the end of gestation and beginning of lactation. Reprod. Nutr. Dev. 22:307-324.

Dulphy, J. P., C. Demarquilly, and M. Henry. 1975. Losses of volatile constituents during the determination of the dry matter content of silages by oven drying. Ann. Zootech. 24:743-756.

Edouard, N., M. Hassouna, P. Robin, and P. Faverdin. 2011. Effect of diet protein level on nitrogen excretion and greenhouse gases emissions in lactating dairy cows. In: Proc. 8th Int. Symp. Nutr. Herbivores, Aberystwyth, UK. p. 534.

Etheridge, R. D., G. M. Pesti, and E. H. Foster. 1998. A comparison of nitrogen values obtained utilizing the Kjeldahl nitrogen and Dumas combustion methodologies (Leco CNS 2000) on samples typical of an animal nutrition analytical laboratory. Anim. Feed Sci. Technol. 73:21-28.

Faisant, N., V. Planchot, F. Kozlowski, M. P. Pacouret, P. Colonna, and M. Champ. 1995. Resistant starch determination adapted to products containing high levels of resistant starch. Sci. Aliments 15:83-89.

Firkins, J. L. 1996. Maximizing microbial protein synthesis in the rumen. J. Nutr. 126:1347S-1354S.

Hart, S. P., and C. E. Polan. 1984. Simultaneous extraction and determination of ytterbium and cobalt ethylenediaminetetracetate complex in feces. J. Dairy Sci. 67:888-896.

Hoover, W. H. 1986. Chemical factors involved in ruminal fiber digestion. J. Dairy Sci. 69:2755-2766.

Hristov, A. N., and J. P. Jouany. 2005. Factors affecting the efficiency of nitrogen utilization in the rumen. In: A. N. Hristov and E. Pfeffer, editors, Nitrogen and phosphorus nutrition of cattle and environment. CAB Int., Wallingford, UK. p. 117-166.

Huhtanen, P., and A. N. Hristov. 2009. A meta-analysis of the effects of dietary protein concentration and degradability on milk protein yield and milk N efficiency in dairy cows. J. Dairy Sci. 92:3222-3232.

INRA. 2007. Nutrition of cattle, sheep and goats: Animal needsValues of feeds. Quae Ed., Paris.

Jouany, J. P. 1982. Volatile fatty acid and alcohol determination in digestive contents, silage juices, bacterial cultures and anaerobic fermentor contents. Sci. Aliments 2:131-144. 
Kalscheur, K. F., R. L. Baldwin VI, B. P. Glenn, and R. A. Kohn. 2006. Milk production of dairy cows fed differing concentrations of rumen-degraded protein. J. Dairy Sci. 89:249-259.

Kebreab, E., J. France, D. E. Beever, and A. R. Castillo. 2001. Nitrogen pollution by dairy cows and its mitigation by dietary manipulation. Nutr. Cycl. Agroecosyst. 60:275-285.

Klusmeyer, T. H., R. D. Mc Carthy Jr., J. H. Clark, and D. R. Nelson. 1990. Effects of source and amount of protein on ruminal fermentation and passage of nutrients to the small intestine of lactating cows. J. Dairy Sci. 73:3526-3537.

Lapierre, H., and G. E. Lobley. 2001. Nitrogen recycling in the ruminant: A review. J. Dairy Sci. 84(E. Suppl.):E223-E236.

Lassalas, B., J. P. Jouany, and L. Broudiscou. 1993. Dosage des bases puriques et pyrimidiques par chromatographie liquide à haute performance. Ann. Zootech. 42:170-171.

Martin, C., and B. Michalet-Doreau. 1995. Variations in mass and enzyme activity of rumen microorganisms: Effect of barley and buffer supplements. J. Sci. Food Agric. 67:407-413.

Mc Carthy, R. D., Jr., T. H. Klusmeyer, J. L. Vicini, J. H. Clark, and D. R. Nelson. 1989. Effects of source of protein and carbohydrate on ruminal fermentation and passage of nutrients to the small intestine of lactating cows. J. Dairy Sci. 72:2002-2016.

Michalet-Doreau, B., and M. Doreau. 2001. Influence of drastic underfeeding on ruminal digestion in sheep. Anim. Res. 50:451462.

Ministère de l'Alimentation, de l'Agriculture et de la Pêche. 2009. Arrêté no. AGRG0927736A du 30 novembre 2009 modifiant l'arrêté du 19 avril 1988 fixant les conditions d'attribution de l'autorisation de pratiquer des expériences sur les animaux. J. Off. Répub. Fr. 1 Dec. http://www.afstal.com/medias/File/arrete-30-novembre-2009.pdf. (Accessed 21 June 2012.)

Noll, F. 1974. L-(+) lactate determination with LDH, GTP and NAD. In: H. U. Bergmeyer, editor, Methods of enzymatic analysis. Verlag Chemie, Weinheim. p. 1475-1479.

Nozière, P., J. M. Besle, C. Martin, and B. Michalet-Doreau. 1996. Effect of barley supplement on microbial fibrolytic enzyme activities and cell wall degradation rate in the rumen. J. Sci. Food Agric. 72:235-242.

NRC. 2001. Nutrient requirements of dairy cattle. 7th rev. ed. Natl. Res. Counc., Washington, DC.

Olmos Colmenero, J. J., and G. A. Broderick. 2006. Effect of dietary crude protein concentration on milk production and nitrogen utilization in lactating dairy cows. J. Dairy Sci. 89:1704-1712.

Owens, F. N., and C. F. Hanson. 1992. External and internal markers for appraising site and extent of digestion in ruminants. J. Dairy Sci. 75: 2605-2617.

Peyraud, J. L., S. Le Liboux, and R. Vérité. 1997. Effect of the level and nature of the source of rumen degradable nitrogen on ruminal digestion in dairy cow fed with a maize silage based diet. Reprod. Nutr. Dev. 37:313-328.
Poncet, C., and D. Rémond. 2002. Rumen digestion and intestinal nutrient flows in sheep consuming pea seeds: The effect of extrusion or chestnut tannin addition. Anim. Res. 51:201-216.

Potts, T. J. 1967. Colorimetric determination of urea in feeds (Report of AOAC Committee). J. AOAC Int. 50:56-58.

Rémond, D., L. Bernard, I. Savary-Auzeloux, and P. Nozière. 2009. Partitioning of nutrient net fluxes across the portal-drained viscera in sheep fed twice daily: Effect of dietary protein degradability. Br. J. Nutr. 102:370-381.

Reynal, S. M., and G. A. Broderick. 2005. Effect of dietary level of rumen-degraded protein on production and nitrogen metabolism in lactating dairy cows. J. Dairy Sci. 88:4045-4064.

Sauvant, D., and P. Nozière. 2011. Evaluation of the microbial synthesis in the rumen and of the PDI system to predict the protein supplies. Rencontres Rech. Rumin. 18:113-116.

Sauvant, D., and J. Van Milgen. 1995. Dynamic aspects of carbohydrates and protein breakdown and the associated microbial matter synthesis. In: W. v. Engelhardt, S. Leonhard-Marek, G. Breves, and D. Giesecke, editors, Ruminant physiology: Digestion, metabolism, growth and reproduction. Ferdinand Enke Verlag, Stuttgart, Germany. p. 71-91.

Siddons, R. C., J. Paradine, D. E. Beever, and P. R. Cornell. 1985. Ytterbium acetate as a particulate-phase digesta-flow marker. Br. J. Nutr. 54:509-519.

Spanghero, M., and Z. M. Kowalski. 1997. Critical analysis of N balance experiments with lactating cows. Livest. Prod. Sci. 52:113-122.

Steinfeld, H., P. Gerber, T. Wassenaar, V. Castel, M. Rosales, and C. De Haan. 2006. Livestock's long shadow: Environmental issues and options. Food Agric. Organ., Rome.

Tamminga, S. 1992. Nutrition management of dairy cows as a contribution to pollution control. J. Dairy Sci. 75:345-357.

Valkeners, D., A. Théwis, M. Van Laere, and Y. Beckers. 2008. Effect of rumen-degradable protein balance deficit on voluntary intake, microbial protein synthesis, and nitrogen metabolism in growing double-muscled Belgian Blue bulls fed corn silage-based diet. J. Anim. Sci. 86:680-690.

Van Soest, P. J., J. B. Robertson, and B. A. Lewis. 1991. Methods of dietary fiber, neutral detergent fiber, and nonstarch polysaccharides in relation to animal nutrition. J. Dairy Sci. 74:3583-3597.

Weatherburn, M. W. 1967. Phenol-hypochlorite reaction for determination of ammonia. Anal. Chem. 39:971-973.

Yang, W. Z., K. A. Beauchemin, K. M. Koenig, and L. M. Rode. 1997. Comparison of hull-less barley, barley, or corn for lactating cows: Effects on extent of digestion and milk production. J. Dairy Sci. 80:2475-2486. 
References

This article cites 46 articles, 4 of which you can access for free at: http://www.journalofanimalscience.org/content/91/2/895\#BIBL 